\title{
Reconsidering survival
}

$\mathrm{T}$

here are no greater threats to the health of humanity than nuclear weapons and climate change, threats that paradoxically have arisen from human behaviour. Nuclear weapons arise out of the human proclivity for war and climate change from our troubled relationship to the natural world. From an evolutionary perspective, both are attempts at survival and adaptation that have gone badly awry.

Like other male primates, humans hunt and kill members of their own species. Historically, war has led to an evolutionary adaptive advantage for the victorious tribe, the winners passing on their genes. Thus, it is hardly surprising that the tools of war, weapons, have been developed through the centuries with ever-greater capacities for killing and destruction. This trajectory has led to an end-game - nuclear weapons, which have rendered the survival advantage of war meaningless. Nevertheless, since the invention of nuclear weapons over half a century ago, the inherent competitive drive of war has led to their proliferation rather than their abolition.

Initially, with the onset of the Cold War and the nuclear arms race, anxiety about this newly created apocalyptic weapon was expressed through the illusory protection of civil defence. Air raid drills and bomb shelters abounded in the r95os. However, public enthusiasm for these measures soon waned as their futility in response to a nuclear attack became increasingly apparent. Gradually, over the decades, we have become psychologically numbed to the enduring and proliferating existence of nuclear weapons. Each headline announcing a new member of the nuclear club is briefly met with alarm but quickly fades o into yesterday's news. The goal of global nuclear disarmament has become a quaint anachronism, rarely raised in the discourse of the mainstream media.

Now we face further potential obliteration, this time in the form of climate

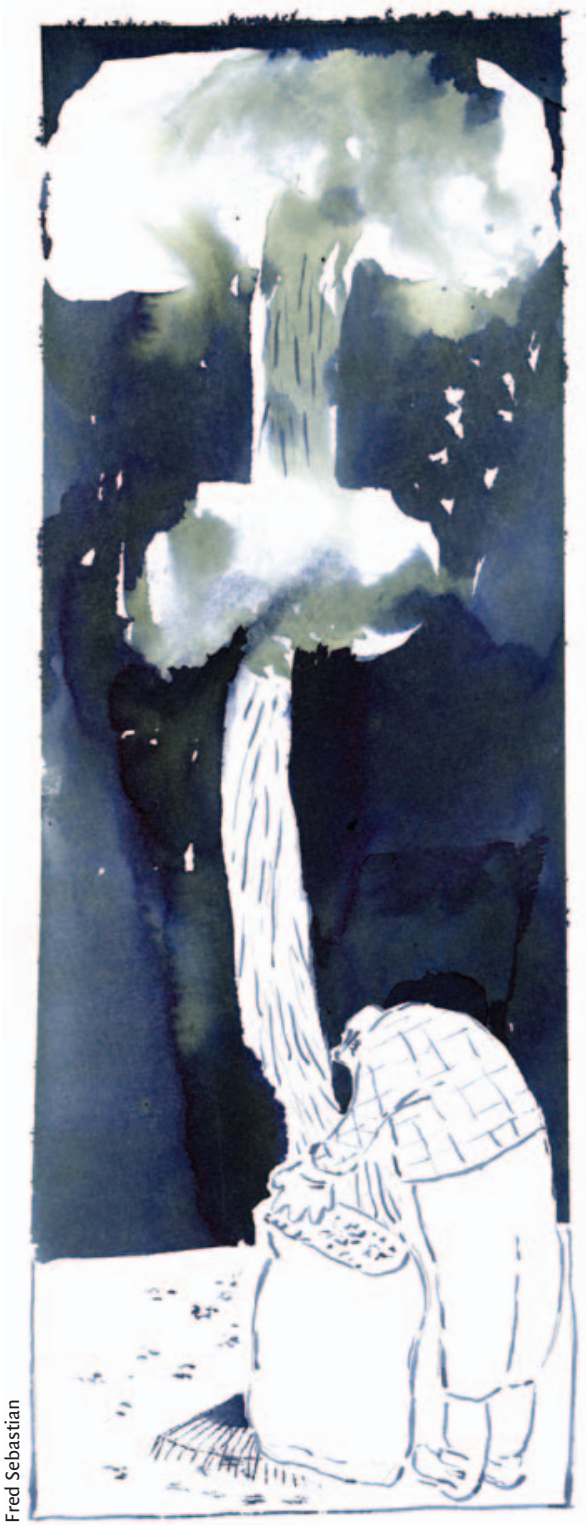

change and impending environmental collapse. As with nuclear weapons, this crisis arose out of what was once an evolutionary, adaptive advantage. $\mathrm{Hu}$ mans who have been able to fashion and mould their surroundings, like victorious tribes, have had a greater chance of passing on their genes. However, this capacity, like weapons, has hypertrophied into a maladaptive disadvantage by overly disrupting the habitat in which the species as a whole resides.
The abundant evidence of climate change and environmental degradation is everywhere to be seen: melting ice caps, raging storms and burning forests. Unlike the hypothetical threat of nuclear war, climate change is a phenomenon that is tangible and readily apparent every day. Thus, by its nature, it consistently and unmercifully challenges our denial and forces us, at a most fundamental level, to redefine our notions of survival. The solution to the environmental crisis requires human cooperation and living in harmony with the natural world. This is in diametric contradistinction to the destructive competition of war that obliterates human lives and harms the physical world. We cannot address climate change and our countless environmental concerns if we persist with the institution of war. We simply cannot afford to direct our energies, efforts and resources toward the destruction of the planet and its preservation at the same time.

Climate change, in confronting us with its ominous truths, offers us both opportunities and challenges: the opportunity to recreate ourselves, the challenge to evolve beyond our instinctual predilections in reconsidering and redressing how we live with each other and with the earth we inhabit, and, ultimately, the opportunity and the challenge to reimagine and reinvent our understanding of how we pursue survival.

\section{Mark Leith MD}

Mark Leith is studying psychotherapy at the University of Toronto, and is the author of Problem Solving Psychotherapy: A Training Manual of an Integrative Model (Trafford, 2006).

Have you got an opinion about this article? Post your views at cmaj.ca. Potential Salon contributors are welcome to send a query to salon@cma.ca 